\title{
ONION MEAL AND ONION EXTRACTS (Allium cepa L.) AS NATURAL GROWTH PROMOTERS FOR USE IN POULTRY PRODUCTION: A REVIEW
}

\author{
Malematja, E. - NG’Ambi, J. W. - Chitura, T. ${ }^{*}$ - Nemauluma, M. F. D. - Kolobe, S. D. - \\ MANYELO, T. G. \\ Department of Agricultural Economics and Animal Production, University of Limpopo, Private \\ Bag X1106, Sovenga 0727, South Africa \\ ${ }^{*}$ Corresponding author \\ e-mail: teedzai.chitura@ul.ac.za \\ (Received $5^{\text {th }}$ Aug 2021; accepted $1^{\text {st }}$ Oct 2021)
}

\begin{abstract}
The objective of this paper is to present a comprehensive understanding of the potential use of onion extracts (Allium cepa L.) as growth promoters in poultry production. The threat of antibiotic residues in poultry meat products to the human population, prohibit the use of antibiotics as feed additives and calls for the need to explore alternatives to synthetic growth promoters. Some attempt has been made to improve poultry performance and health condition through feeding the animal root tubers such as garlic, onions, and ginger. Root tubers contain various phytochemical compounds, flavonoids, and phenolic acids with confirmed anti-inflammatory, antibacterial, antioxidant, and growth promoting properties. Bioactive compounds in root tubers influence animal growth performance through enhanced digestibility and by altering gut health. The use of these tubers and their extracts has been shown to have non-toxic and nonpathogenic effects on birds; hence these tubers could be an alternative to antibiotics. Therefore, the onion bulb shows a tremendous potential as a natural growth promoter and a phytogenic natural feed additive alternative to synthetic growth promoters.
\end{abstract}

Keywords: antibiotics, growth performance, carcass quality, gut morphology, bioactive compounds, root tubers

\section{Introduction}

High feed costs which are partially attributable to the price fluctuations of feed ingredients present a major challenge to successful poultry production. This often results in the use of feed ingredients and feed additives that are cheap and of low quality in an effort to improve nutrient exploitation by the bird (Mammo, 2012; Mulugeta et al., 2019). Adding feed additives (synthetic or organic) to poultry diets maximizes nutrient exploitation by the bird thereby improving growth performance and feed conversion efficiency (Mulugeta et al., 2019). Synthetic additives have been used in poultry production for several decades and their over-usage resulted in the emergence of drugresistant microorganisms in both poultry production and in the human population (Casewell et al., 2003; Yadav et al., 2016). Researchers are currently challenged with finding alternative ways of synchronizing the growth performance in poultry production to substitute synthetic drugs using organic growth promoters while minimizing the cost of production as well as adverse effects on human health (Iji et al., 2001; Khaidem et al., 2019). Medicinal plants or herbal extracts almost meet the nutrients required by the animals and contain unique organic phytochemicals that are believed to promote optimum health in birds (Yousuf et al., 2013). Several studies have reported positive effects of onion extracts on poultry production in terms of feed efficiency and weight gain (Guo et al., 2000; Demir et al., 2003; Ahmad et al., 2008; Mulugeta et al., 2019). These observations press a high demand for natural growth promoters as feed ingredients in the 
future. Therefore, this review aimed to provide a comprehensive understanding of the potential use of onion extracts as alternative natural growth promoters in poultry production.

\section{Source of data}

The data used in this review was acquired from recent articles that were published in different journals. Databases were accessed using electronic data sources such as Research gate, Science direct, and Google scholar. In addition, the citations included in articles from the databases were used to search for other relevant articles. In the search process, the key words were "Onion meal', "Onion extracts", and "poultry".

\section{Structure and growth requirements of the onion bulb}

Allium cepa commonly known as an onion is a vegetable crop that belongs to the family Liliaceae. It originated from central Asia and is now being cultivated throughout the world, Asia and North America being the most producing continents (Ebesunum et al., 2007; Obasi et al., 2009; Iqbal and Bayram, 2019). Onion is a short duration horticultural crop, and its cultivars differ from biannual to perennial cultivar (Brewster, 2008). The onion crop has green tubular leaves and a bulb with shallow adventitious fibrous roots (Pareek et al., 2017). The crop goes through three growth stages, namely germination, bulb initiation, and flowering stages. It is planted by seeds or bulbs (Brewster, 2008). Although the crop is cultivated under various temperatures, it does not do well under extremely hot or cold conditions (Brewster, 2008). The onion crop is planted on the field for $4-6$ months under rainfall or irrigated conditions, through seed or propagations (Bulb) (Abdissa et al., 2011). Onion bulbs produce a smell when crushed and the bulb is the commonly used portion of the plant (Liguori et al., 2017; Pareek et al., 2017). It can be used in the form of onion-extracts or powder (Pareek et al., 2017). The nutritive and energy value of onions depend on their origin, cultivars, harvesting stage as well as the period of storage (Pareek et al., 2017). Although onion bulbs appear in different colours, their taste is not influenced by the colour, but by the cultivar (Kandoliya et al., 2015).

\section{Nutritional values and the chemical compositions of onion bulbs}

Proximate analysis reveals that raw onion bulbs contain high moisture levels $(89.11 \%)$, less fibre $(1.7 \%)$, ash $(0.35 \%)$, carbohydrates $(0.35 \%)$, and very little proteins $(1.1 \%)$, fats $(0.1 \%)$, and energy content (40 kcal) (Pareek et al., 2017). Bhattacharjee et al. (2013) reported a low ash level $(0.25 \%)$, protein content $(1.49 \%)$ in the Indian and Bangladeshi varieties of onion respectively. The Ash content of the feed provides the level of mineral elements that are present in the feedstuff (Edeogu et al., 2007). Onion has a low-fat content $(0.7 \%)$, as well as low dietary fibre $(1.92 \%)$ and calories. However, it is a good source of minerals and vitamins (Kandoliya et al., 2015; Ogbonna et al., 2016). High moisture level makes the onion to be more prone to deterioration, however, it helps the animal body to use less of its fluid for digestion (Bhattacharjee et al., 2013). Dietary fibre in the onion bulb helps in the digestion and regulation of oxidants in feed ingredients (Bhattacharjee et al., 2013). Energy and aromatic amino acids are derived from sugars and carbohydrates contained in the onion bulb (Kandoliya et al., 2015). Carbohydrates 
are also suggested to be an alternative source of glucose (Bhattacharjee et al., 2013). Onion bulbs are regarded as a good source of antioxidants and phytonutrients (Kandoliya et al., 2015). Nutritional values and chemical compositions of onion bulbs are presented in Table 1.

Table 1. Nutritional values and the chemical compositions of raw onion bulbs (in percentages)

\begin{tabular}{c|c|c}
\hline Nutrient & Composition & References \\
\hline Proximate & & \\
\hline Moisture & 89.11 & Pareek et al. (2017) \\
Protein & 1.1 & Pareek et al. (2017) \\
& 1.489 & Bhattacharjee et al. (2013) \\
Lipids & 1.27 & Kandoliya et al. (2015) \\
& 0.1 & Pareek et al. (2017) \\
Ash & 0.17 & Ogbonna et al. (2016) \\
& 0.248 & Bhattacharjee et al. (2013) \\
& 0.66 & Ogbonna et al. (2016) \\
\hline \multirow{2}{*}{ Carbohydrates } & 0.35 & Pareek et al. (2017) \\
& 0.35 & Pareek et al. (2017) \\
& 14.772 & Bhattacharjee et al. (2013) \\
& 6.91 & Ogbonna et al. (2016) \\
\hline \multirow{2}{*}{ Fiber } & 1.7 & Pareek et al. (2017) \\
& 1.659 & Bhattacharjee et al. (2013) \\
\hline Energy & 1.92 & Ogbonna et al. (2016) \\
\hline
\end{tabular}

\section{Bioactive compounds in onion bulbs}

Phytochemicals are biologically active compounds produced by plants to prevent infections (in roots, stem, leaves, flowers, or seeds) and are known to be beneficial to human and animal health (Rao, 2003; Saxena et al., 2013). Phytochemicals are present in a wide range of vegetables, grains, root tubers, herbs, and spices (Moorachian, 2000; Saxena et al., 2013). Bioactive phytochemicals mainly come from medicinal plants and root tubers such as onions and garlic which are common sources of phytochemicals and their concentration levels vary among plant species and cultivars, the growing environment, and the applied method of processing (Edeoga et al., 2005; Saxena et al., 2013). Onion bulbs have been characterised to contain plethora bioactive compounds such as organosulfur compounds, polysaccharides, saponins, fructants, and phenolic compounds (Saxena et al., 2013). Organosulfur compounds are the main bioactive compounds in onion bulbs and sulfur-containing compounds such as cysteine sulfoxides, quercetin, quercetin glucosides, and allicin are the major organosulfur compounds in onion bulbs (Kothari et al., 2019; Zhao et al., 2021). Organosulfur compounds are associated with antioxidants and antimicrobial activities (Kothari et al., 2019). Antioxidant compounds include polyphenolic, flavonoids, carotenoids, tocopherols, and ascorbic acid. whereas antimicrobial compounds include terpenoids, alkaloids, and phenolic which exert their effects through the stimulation of the immune system to fight against infections (Saxena et al., 2013; Kothari et al., 2019). Saponins in onion bulbs have been validated to contain biological properties such antifungal as well as antiinflammatory properties (Kothari et al., 2019). These compounds stimulate and improve growth performance and health condition of birds through appetizing and stimulation of 
the digestive system and immune response (Guo et al., 2000). Phytochemical compounds enhance growth through induced nutrient utilization by the animal (Noman et al., 2015). Other phytochemical compounds include non-starch polysaccharides (cellulose, hemicellulose, pectins, and lignins) which delay the process of nutrient absorption, bind toxins, and bile acids (Saxena et al., 2013).

\section{Utilisation of onion meal or onion extracts in poultry production reared under stress free environment}

Among domesticated animals, poultry convert feed more efficiently than other animals. The maintenance of high feed conversion is crucial for birds to grow faster and reach the market weight early (Diaz et al., 2019). Medicinal plants and other plant extracts have been used as digestion stimulants as well as growth promoters in livestock production (Frankic et al., 2009). Lampe (1999), Aji et al. (2011) and Goodarzi et al. (2013) reported a positive effect of onion meal dietary inclusion on the growth performance of chickens. Onion possesses phytochemical compounds such as antioxidant properties, antimicrobial effect, and anti-inflammatory properties and there is evidence indicating that onion bulbs could improve the growth performance of birds when mixed in their diets. Goodarzi et al. (2013) further stated that onion bulbs or their extracts exert an influence on growth performance in chickens. It has been reported that onion powder in livestock feed or onion extracts in drinking water have growth promoting as well as anti-pathogen activities (Goodarzi and Nanekarani, 2014). Aditya et al. (2017) reported that the inclusion of onion meal or onion extracts at appropriate levels could improve broiler performance and productivity. There is evidence indicating that onion meal inclusion in the diets of broiler chickens could improve feed intake due to the favourable taste of processed onions and this in turn can improve the bodyweight of the chickens (Aditya et al., 2017). Metabolism systems in poultry species are similar, therefore, the influence of onion extracts on performance is the same throughout the poultry species (Keohavong and Bounyavong, 2018). Aditya et al. (2017) reported that onion inclusion level of 5 or $7.5 \mathrm{~g}$ into broiler diets improved overall feed intake and body weight of broiler chickens with unaffected feed conversion ration over a four-week trial period, however, its positive effect seemed to disappear when the supplementation levels are too high. Onion extracts supplementation of up to $1 \%$ in drinking water could improve average daily feed without affecting feed conversion ratio of broiler chickens during the stater and grower period (Goodarzi and Nanekarani, 2014). According to Aji et al. (2011), supplementing $25 \mathrm{mg}$ of onion per $\mathrm{kg}$ DM increased body weight gain while no effects were observed on daily feed and water intake, however, increasing onion supplementation level to $100 \mathrm{mg}$ of onion per $\mathrm{kg}$ DM had increased feed and water intake, feed conversion ratio, and live weight of broiler chickens at 21 days. Al-Ramamneh (2018) observed that adding $2.5 \mathrm{~kg} / \mathrm{t}$ or $2.5 \%$ in basal diet or drinking water improved live weights of broiler chickens, while no effect was observed on feed intake until the fourth and fifth week of age when the feed intake was reduced compared to control group. In another study, Al-Ramamneh et al. (2017) reported increased feed intake and daily weight gain in broiler chickens fed diets having 2.5, 5 or $7.5 \mathrm{~kg}$ of onion per ton DM. Ibrahiem et al. (2004) reported increased feed conversion ratio, live body weight, and bodyweight gain in Muscovy ducks fed diets with of $1 \%$ of onion meal. However, Keohavong and Bounyavong (2018) observed that supplementing onion at 1 or $2 \%$ level did not produce effects on the overall growth performance of Muscovy ducks aged 4-8 weeks. Goodarzi 
et al. (2013) reported that adding 10 or $30 \mathrm{~g}$ of fresh onion bulbs into basal diets reduced feed conversion ratio without affecting body weight in broiler chickens during the starter and grower period. However, supplementing $30 \mathrm{~g}$ of fresh onion bulb per $\mathrm{kg} \mathrm{DM}$ increased daily feed intake throughout the experiment as well as body weight at 42 days (Goodarzi et al., 2013). Olusola et al. (2018) reported improved feed conversion ratio was well as an increased body weight gain and final body weight in broiler chickens fed diets with 30 or $100 \mathrm{~g}$ of onion $\mathrm{kg}$ per DM. Waleed et al. (2021) also observed an increased body weight in Japanese quail hens fed diets with $800 \mathrm{~g}$ of dried onion per $\mathrm{kg}$ DM. However, An et al. (2015) observed no effect in feed intake, feed conversion ratio and body weight in white mini broiler chickens supplemented with 0.3 or $0.5 \%$ of onion extracts in basal diets. Effects of dietary onion on poultry production are presented in Table 2.

\section{Effect of onion meal or onion extracts on bird's immune responses}

Allium species have been characterized to contain numerous bioactive compounds such as organosulfur compounds, saponins, fructans, and polyphenols with proven antibacterial, antiviral, and immunostimulatory (Hanieh et al., 2010; Kothari et al., 2019). Bioactive compounds have beneficial effects on the humoral immune responses in animals and onion bulbs or extracts have been validated to have plethora effect on the humoral immune response in chickens (Hanieh et al., 2010; Omar et al., 2020). Immune responses play an important role in protection against various disease (Korpraditskul et al., 2009). Goodarzi et al. (2013) observed that adding 10 or $30 \mathrm{~g}$ of fresh onion bulbs in basal diets did not influence antibody titers against Newcastle virus in broiler chickens aged 14 and 21 days. Similar findings were made by Waleed et al. (2021) who reported that supplementing that onion supplementation of $800 \mathrm{~g}$ per $\mathrm{kg}$ did not enhance humoral immune responses in Japanese quail hens as compared to control group. Hanieh et al. (2010) observed improved immune response against Newcastle disease virus in white leghorn chickens fed diets with $10 \mathrm{~g}$ of onion powder per kg. Moreover, Korpraditskul et al. (2009) and Iqbal and Bayram (2019), reported enhanced humoral immune response against Newcastle virus in broiler and babcock hens fed $2 \%$ of onion extracts or juice in drinking. Omar et al. (2020) also reported an increased in immune responses in broiler chickens fed diets containing $3 \mathrm{~g}$ of phenolic-rich onion extracts per $\mathrm{kg} \mathrm{DM}$. Effects of onion meal or onion extracts inclusion in poultry diets on immune responses under controlled environment (Table 3).

\section{Effects of onion meal or onion extracts in poultry diets on meat quality and sensory evaluation}

Visual appearance and the texture of meat are the major factors that attract consumers to buy meat (Yang and Jiang, 2005). Research on the potential of plant extracts as alternatives to antibiotic growth promoters is popular in the poultry production industry due to consumers' high demand for meat from animals raised with no antibiotics (Yang and Jiang, 2005). Onion meal inclusion in chicken diets has been shown to improve gut morphology and carcass quality of poultry meat (Ur Rahman et al., 2017; Al-Ramamneh, 2018). Al-Ramamneh (2018) reported an increased in carcass weight with heavier meat organ part in broiler chickens fed basal diets with $2.5 \mathrm{~kg} /$ ton DM or $2.5 \%$ in drinking water. 
Table 2. Effects of dietary onion on poultry growth performance

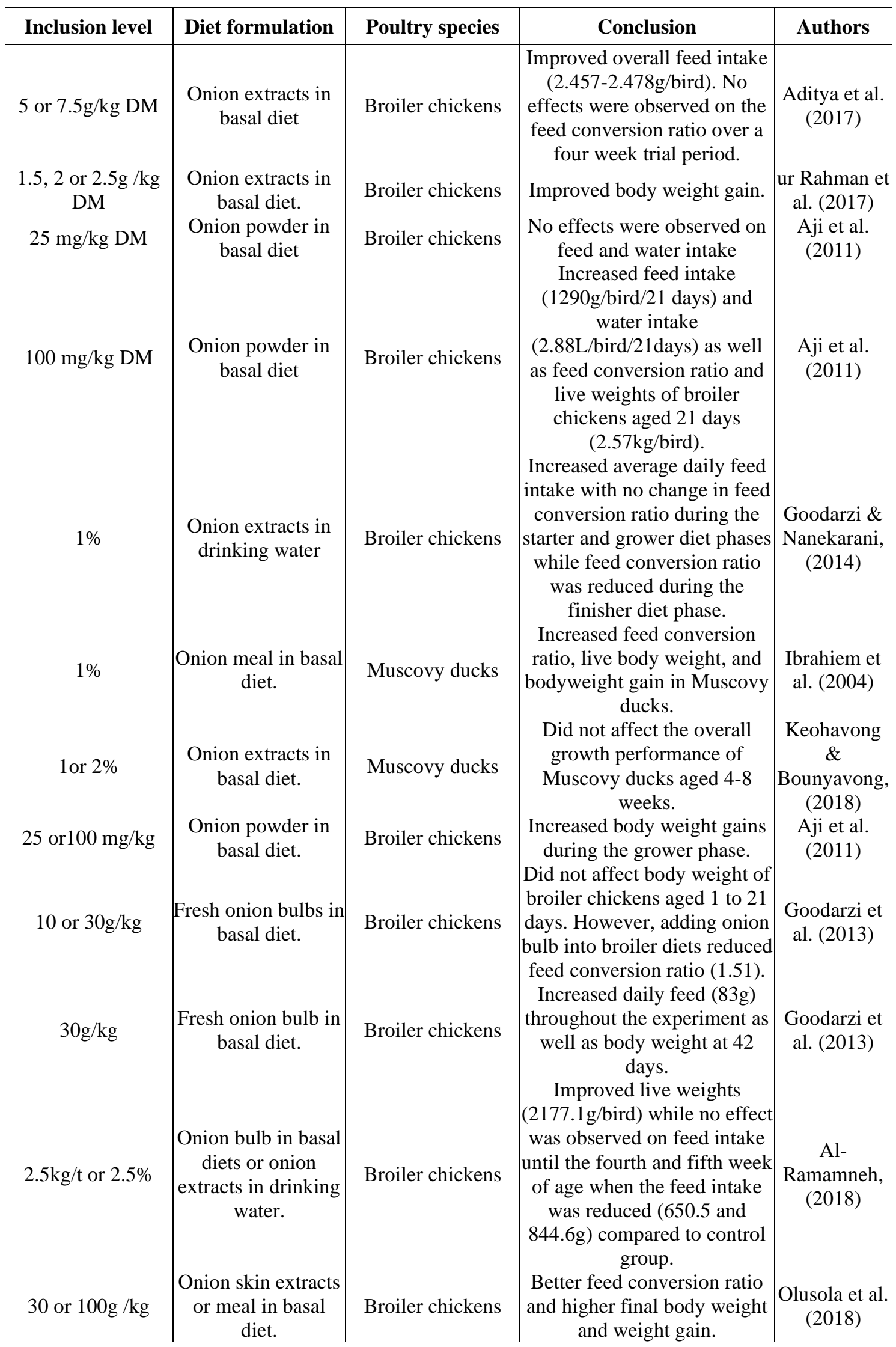




\begin{tabular}{|c|c|c|c|c|}
\hline Inclusion level & Diet formulation & Poultry species & Conclusion & Authors \\
\hline 5 or $7.5 \mathrm{~g} / \mathrm{kg} \mathrm{DM}$ & $\begin{array}{l}\text { Onion extracts in } \\
\text { basal diet. }\end{array}$ & Broiler chickens & \begin{tabular}{|c|} 
Improved body weight \\
(1.694- $1.727 \mathrm{~g} / \mathrm{bird})$ however, \\
its positive effect seemed to \\
disappear when the \\
supplementation levels are \\
too high.
\end{tabular} & $\begin{array}{l}\text { Aditya et al. } \\
\text { (2017) }\end{array}$ \\
\hline $2.5,5$ or $7.5 \mathrm{~kg} / \mathrm{ton}$ & $\begin{array}{l}\text { Onion extracts in } \\
\text { basal diet. }\end{array}$ & Broiler chickens & $\begin{array}{l}\text { Increased feed intake and } \\
\text { daily weight gain. }\end{array}$ & $\begin{array}{l}\text { Al- } \\
\text { Ramamneh et } \\
\text { al. (2017) }\end{array}$ \\
\hline $800 \mathrm{~g} / \mathrm{kg}$ & $\begin{array}{l}\text { Dried onion with } \\
\text { basal diet }\end{array}$ & Japanese quail hens & $\begin{array}{l}\text { Supplementation of onion } \\
\text { increased body weight } \\
\text { compared to the control } \\
\text { group. }\end{array}$ & $\begin{array}{l}\text { Waleed et al. } \\
\text { (2021) }\end{array}$ \\
\hline 0.3 or $0.5 \%$ & $\begin{array}{l}\text { Onion extract } \\
\text { mixed with basal } \\
\text { diet }\end{array}$ & White mini broilers & $\begin{array}{c}\text { Similar body weight, no } \\
\text { improvements feed intake, } \\
\text { and feed efficiency were } \\
\text { observed. }\end{array}$ & $\begin{array}{l}\text { An et al. } \\
(2015)\end{array}$ \\
\hline
\end{tabular}

Table 3. Effects of onion meal or onion extracts inclusion in poultry diets on immune responses

\begin{tabular}{|c|c|c|c|c|}
\hline Inclusion level & Diet Formulation & Poultry species & Conclusion & Authors \\
\hline 10 or $30 \mathrm{~g} / \mathrm{kg}$ & $\begin{array}{c}\text { Dietary treatments } \\
\text { consisted of basal diet } \\
\text { and fresh onion bulb }\end{array}$ & Broiler chickens & $\begin{array}{c}\text { Did not influence antibody } \\
\text { titers against Newcastle } \\
\text { Disease Virus at } 14 \text { and } 21 \\
\text { days of age }\end{array}$ & $\begin{array}{c}\text { Goodarzi et al. } \\
\text { (2013) }\end{array}$ \\
\hline $10 \mathrm{~g} / \mathrm{kg}$ & $\begin{array}{c}\text { Onion powder in basal } \\
\text { diets }\end{array}$ & $\begin{array}{l}\text { White Leghorn } \\
\text { chickens }\end{array}$ & $\begin{array}{c}\text { Exerted enhancing effect } \\
\text { on the humoral immune } \\
\text { responses against } \\
\text { Newcastle Disease Virus. }\end{array}$ & $\begin{array}{l}\text { Hanieh et al. } \\
\qquad(2010)\end{array}$ \\
\hline $2 \%$ & $\begin{array}{l}\text { Onion tree extracts in } \\
\text { drinking water }\end{array}$ & $\begin{array}{c}\text { Arbor Acres Broiler } \\
\text { chickens }\end{array}$ & $\begin{array}{l}\text { Stimulated the humoral } \\
\text { immune response against } \\
\text { Newcastle Disease Virus. }\end{array}$ & $\begin{array}{l}\text { Korpraditskul et } \\
\text { al. (2009) }\end{array}$ \\
\hline $2 \%$ & $\begin{array}{l}\text { Onion juice in } \\
\text { drinking water }\end{array}$ & Babcock hens & $\begin{array}{l}\text { Improved immune } \\
\text { response against the } \\
\text { Newcastle virus. }\end{array}$ & $\begin{array}{c}\text { Iqbal \& Bayram } \\
\text { (2019 }\end{array}$ \\
\hline $800 \mathrm{~g} / \mathrm{kg}$ & $\begin{array}{c}\text { Dried onion with basal } \\
\text { diet. }\end{array}$ & Japanese quail hens & $\begin{array}{c}\text { Onion supplementation } \\
\text { did not exert effect on } \\
\text { humoral immune } \\
\text { response. }\end{array}$ & $\begin{array}{l}\text { Waleed et al. } \\
\qquad(2021)\end{array}$ \\
\hline $3 \mathrm{~g} / \mathrm{kg}$ & $\begin{array}{l}\text { Phenolic-rich onion } \\
\text { extracts in basal diet }\end{array}$ & Broiler chickens & $\begin{array}{l}\text { Significantly improved the } \\
\text { immune response of birds. }\end{array}$ & $\begin{array}{l}\text { Omar et al. } \\
\qquad(2020)\end{array}$ \\
\hline
\end{tabular}

However, several studies reported no effect of onion extracts in basal diets or drinking water on carcass weight of chickens and Muscovy ducks (Aji et al., 2011; Goodarzi and Nanekarani, 2014; Keohavong and Bounyavong, 2018; Omar et al., 2020). An et al. (2015) observed no effects on meat $\mathrm{pH}$ and meat color of the breast meat among groups of white mini broiler chickens fed diets with 0.3 or $0.5 \%$ of onion extracts per $\mathrm{kg} \mathrm{DM}$, however, onion supplementation increased meat-shear force compared to the control group. Aditya et al. (2017) reported affected meat color lightness with the lower values from chickens fed $7.5 \mathrm{~g}$ of onion extracts per $\mathrm{kg} \mathrm{DM}$ and red color of chickens fed onion extracts was lower throughout the treatment period. Keohavong and Bounyavong (2018) 
observed an improved breast meat of Muscovy ducks, in terms of cooking loss. Effect of onion meal or extracts inclusion on carcass characteristics and meat quality of broiler chicken (Table 4).

Table 4. Effects of onion meal or onion extracts inclusion in poultry diets on meat quality

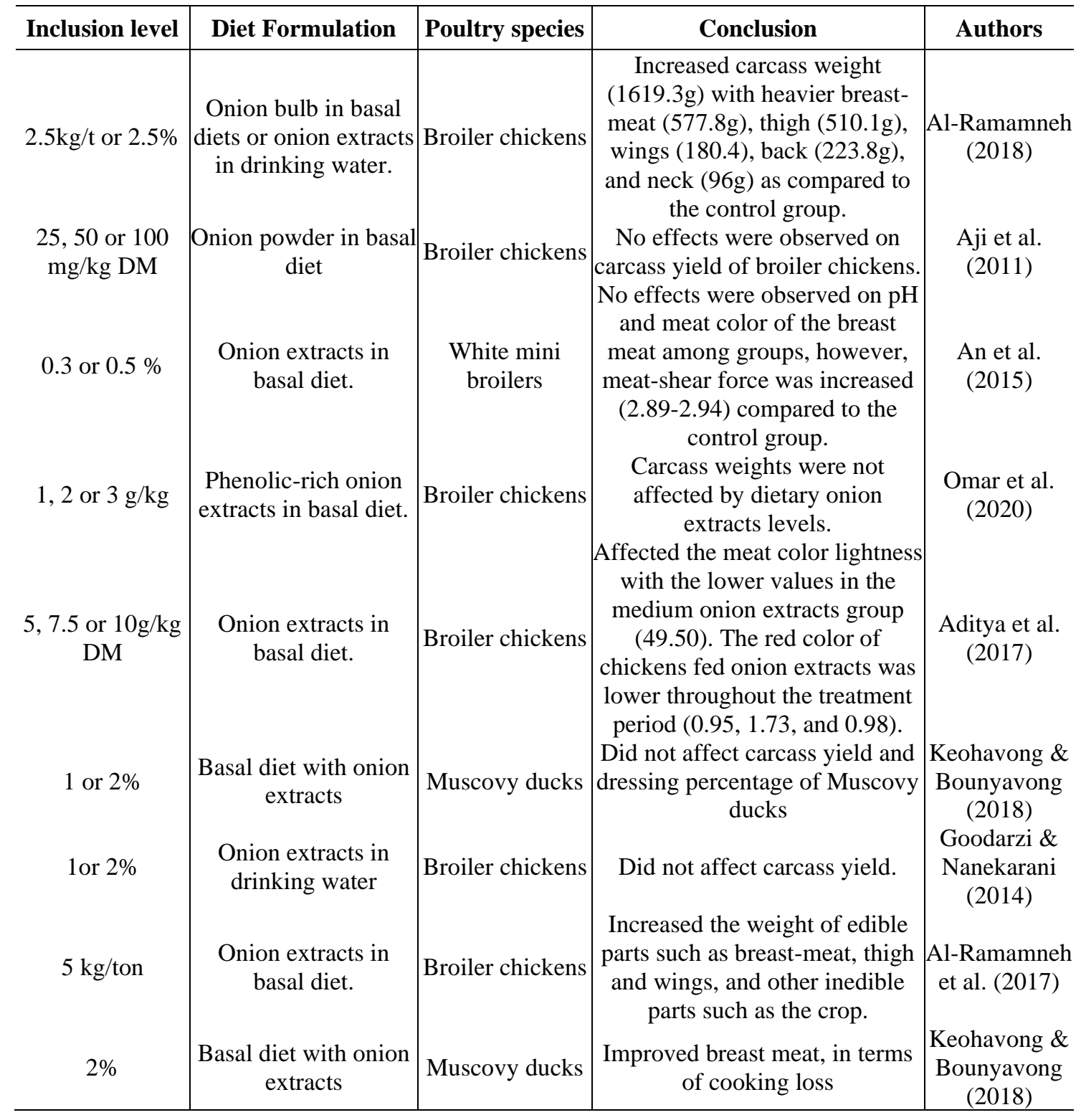

\section{Effect of onion meal or extracts on gut morphology of poultry species}

The structure and functionality of the gut microorganism are vital for the well-being of the bird through influences on nutrient digestion and intestinal integrity (Diaz et al., 2019). The onion bulb contains some compounds that prevent the accumulation of harmful bacterial in the gastrointestinal tract of the bird (Goodarzi and Nanekarani, 2014). Phytochemical compounds in onion change the gut microflora and the gut immune system and promote the proliferation of colonic and mucosal microflora which serve as a wall to prevent the access of bacteria to the gastrointestinal tract (Slavin, 2013). Fructans in onion 
bulb enhance gastrointestinal health through balancing the proportion between beneficial microbial and harmful microbial (Ogbonna et al., 2016). This could lead to efficient feed utilization, resulting in improved health conditions and performance (Bedford, 2000). AlRamamneh et al. (2017) reported no effects of onion meal supplementation level of 2.5, 5 or $7.5 \mathrm{~kg}$ per ton DM on the weight of the internal organs, including the digestive tract of broiler chickens, however, onion meal supplementation in diets had improved small intestinal lengths. Goodarzi and Nanekarani (2014) observed no effect on relative internal organ weight and affected abdominal fat in broiler chickens fed basal diets supplemented with 1 or $2 \%$ onion extracts in drinking water. However, Omar et al. (2020) reported no effect on abdominal fat weights and relative weight of liver, heart, and spleen in broiler chickens fed diets with 5, 7.5 or $10 \mathrm{~g}$ of onion per $\mathrm{kg}$ DM. Adding $2.5 \mathrm{~g}$ of onion meal into broiler diets had increased the dimension, crypt depth, and the surface area of the duodenum, jejunum, and ileum of broiler chickens (Ur Rahman et al., 2017). Supplementing $2.5 \mathrm{~kg}$ per ton or $2.5 \%$ of onion into broiler diets increased liver weight, however, the abdominal fat and heart weight were negatively affected as compared to the control (Al-Ramamneh, 2018). Effect of onion meal or extracts inclusion on gut morphology of poultry species (Table 5).

Table 5. Effect of onion meal or extracts on gut morphology of poultry species

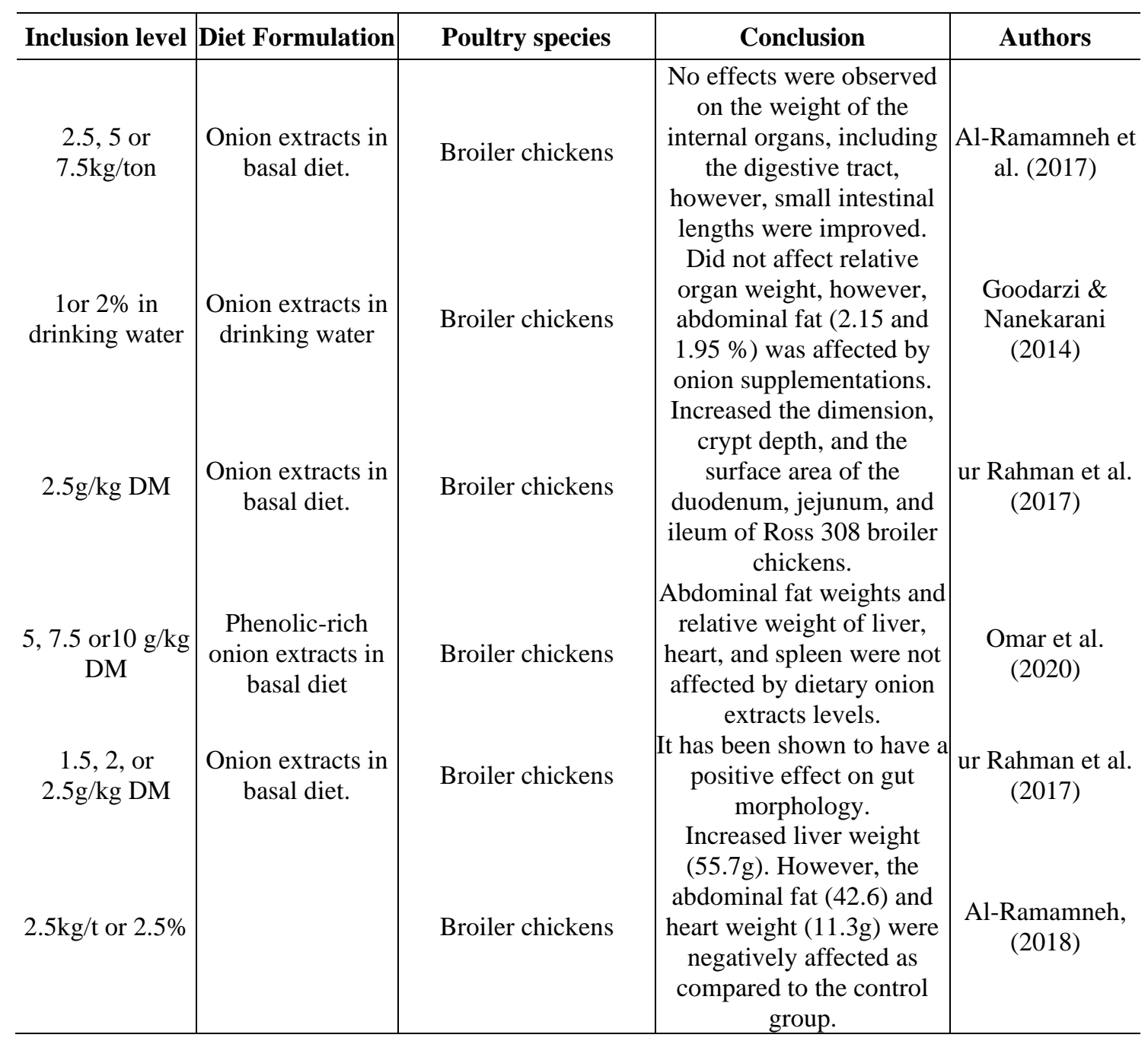




\section{Effects of onion meal or onion extracts inclusion in poultry diets on egg quality of laying hens reared under stress free environment}

Iqbal and Bayram (2019) reported that onion juice supplementation from 0.25 to $2 \%$ in drinking water did not improve egg weight as well as egg shell weight during 30 days storage at $4^{0} \mathrm{C}$. However, increasing onion juice supplementation level up to $2 \%$ had resulted in an increased egg production, while $0.5 \%$ onion juice in drinking water showed a remarkable improvement in egg weight whereas $0.25 \%$ of onion juice supplementation had negatively affected egg weight in babcock hens. Damaziak et al. (2017) observed improved egg weights from laying hens fed diets with $0.0032 \%$ of onion powder in diets, however, onion powder supplementation delayed laying process. Onion supplementation of $800 \mathrm{~g}$ per $\mathrm{kg}$ in basal diets did not produce effects on egg production rate as well as egg weight in Japanese quail hens (Waleed et al., 2021). Effects of onion meal or onion extracts inclusion in poultry diets on egg quality of laying hens (Table 6).

Table 6. Effects of onion meal or onion extracts inclusion in poultry diets on egg quality of laying hens under controlled environment

\begin{tabular}{|c|c|c|c|c|}
\hline Inclusion level & Diet Formulation & Poultry species & Conclusion & Authors \\
\hline $0.25,0.5,1$ or $2 \%$ & $\begin{array}{l}\text { Onion juice in } \\
\text { drinking water }\end{array}$ & Babcock hens & \begin{tabular}{|} 
Adding onion juice in \\
water had no effect on egg \\
weight and shell weight \\
throughout a 30 days \\
storage at $4{ }^{\circ} \mathrm{C}$.
\end{tabular} & $\begin{array}{c}\text { Iqbal \& Bayram } \\
\text { (2019) }\end{array}$ \\
\hline $0.5 \%$ & $\begin{array}{l}\text { Onion juice in } \\
\text { drinking water }\end{array}$ & Babcock hens & $\begin{array}{l}\text { Significantly increased } \\
\text { egg weights }(58.6 \mathrm{~g}) \text { as } \\
\text { compared to other levels } \\
\text { and control group. } \\
\text { Egg weight was }\end{array}$ & $\begin{array}{l}\text { Iqbal \& Bayram } \\
\text { (2019 }\end{array}$ \\
\hline $0.25 \%$ & $\begin{array}{l}\text { Onion juice in } \\
\text { drinking water }\end{array}$ & Babcock hens & $\begin{array}{c}\text { negatively affected } \\
\text { (48.1g) by onion juice in } \\
\text { drinking water. }\end{array}$ & $\begin{array}{l}\text { Iqbal \& Bayram } \\
\text { (2019 }\end{array}$ \\
\hline $2 \%$ & $\begin{array}{l}\text { Onion juice in } \\
\text { drinking water }\end{array}$ & Babcock hens & $\begin{array}{l}\text { Egg production was } \\
\text { increased by onion } \\
\text { supplementation }\end{array}$ & $\begin{array}{l}\text { Iqbal \& Bayram } \\
\qquad(2019\end{array}$ \\
\hline $0.0032 \%$ & $\begin{array}{c}\text { Onion powder with } \\
\text { basal diet }\end{array}$ & Laying hens & $\begin{array}{l}\text { Onion meal inclusion in } \\
\text { the diets improved egg } \\
\text { weight ( } 56 \mathrm{~g}) \text { as compared } \\
\text { to control group. } \\
\text { However, egg production } \\
\text { was delayed. }\end{array}$ & $\begin{array}{l}\text { Damaziak et al. } \\
\qquad(2017)\end{array}$ \\
\hline $800 \mathrm{~g} / \mathrm{kg}$ & $\begin{array}{c}\text { Dried onion powder } \\
\text { with basal diet }\end{array}$ & $\begin{array}{l}\text { Japanese quail } \\
\text { hens }\end{array}$ & $\begin{array}{l}\text { Onion supplementation } \\
\text { did not affect laying rate } \\
\text { as well the egg weight as } \\
\text { compared to the control } \\
\text { group. }\end{array}$ & Waleed et al. (2021) \\
\hline
\end{tabular}

\section{Conclusions and recommendations}

Due to the emergence of drug-resistant microorganisms as well as the threat of drug residues in poultry meat and meat products, attempts are being made to find alternative means to substitute synthetic growth promoters. Therefore, onions show significant potential to be used in poultry diets as natural growth promoters as well as possible 
alternative means of preventing infectious diseases through the enhanced immune response of birds. There is evidence that onion bulbs can be used as natural growth promoters to improve the growth performance and productivity of chickens. Onions contain various biological chemical compounds, flavonoids, and phenolic acids with verified antibacterial, antioxidant, and anti-inflammatory properties. Therefore, onions could be used as alternative and sustainable growth promoters in poultry feeds considering their inherent high nutritional values and high biosafety levels. Most researchers revealed that onion meal or extracts supplementation in basal diets improved growth performance in birds. However, more studies are recommended to establish the appropriate onion dosage or inclusion level, age of application and conditions under which onion meal or extracts can be applied.

Acknowledgements. Authors would like to acknowledge University of Limpopo, Department of Agricultural Economics and Animal Production for resources made available to conduct this paper.

\section{REFERENCES}

[1] Abdissa, Y., Tekalign, T., Pant, L. M. (2011): Growth, bulb yield and quality of onion (Allium cepa L.) as influenced by nitrogen and phosphorus fertilization on vertisol I. growth attributes, biomass production and bulb yield. - African Journal of Agricultural Research 6(14): 3252-3258.

[2] Aditya, S., Ahammed, M., Jang, S. H., Ohh, S. J. (2017): Effects of dietary onion (Allium сера) extract supplementation on performance, apparent total tract retention of nutrients, blood profile, and meat quality of broiler chicks. - Asian-Australasian Journal of Animal Sciences 30(2): 229.

[3] Ahmad, T., Ansari, J. Z., Haq, A., Yousaf, M., Khan, S. (2008): Evaluation of different medicinal plants as growth promoters for broiler chicks. - Sarhad Journal of Agriculture 24(2): 323-329.

[4] Aji, S., Ignatius, K., Ado, A. Y., Nuhu, J. B., Abdulkarim, A., Aliyu, U., Numa, P. (2011): Effects of feeding onion (Allium cepa) and garlic (Allium sativum) on some performance characteristics of broiler chickens. - Research Journal of Poultry Sciences 4(2): 22-27.

[5] Al-Ramamneh, D., Almassed, M., Hussein, N. (2017): Effect of using onion as anticoccidial agent on broiler physiology and production. - Bulletin of Environment, Pharmacology, and Life Science 6: 87-92.

[6] Al-Ramamneh, D. (2018): Reduce Heat Stress in Broiler by Adding Onion. - Russian Agricultural Sciences 44(1): 92-96.

[7] An, B. K., Kim, J. Y., Oh, S. T., Kang, C. W., Cho, S., Kim, S. K. (2015): Effects of onion extracts on growth performance, carcass characteristics, and blood profiles of white mini broilers. - Asian-Australasian Journal of Animal Sciences 28(2): 247.

[8] Bedford, M. (2000): Removal of antibiotic growth promoters from poultry diets: implications and strategies to minimize subsequent problems. - World Poultry Science 56(4): 347-365.

[9] Bhattacharjee, S., Sultana, A., Sazzad, M. H., Islam, M. A., Ahtashom, M., Asaduzzaman, M. (2013): Analysis of the proximate composition and energy values of two varieties of onion (Allium cepa L.) bulbs of different origin: A comparative study. - International Journal of Nutrition and Food Sciences 2(5): 246-253.

[10] Brewster, J. L. (2008): Onions and Other Vegetable Alliums. - Wallingford, UK. -CAB international 15. 
[11] Casewell, M., Friis, C., Marco, E., McMullin, P., Phillips, I. (2003): The European ban on growth-promoting antibiotics and emerging consequences for human and animal health. Journal of Antimicrobial Chemotherapy 52(2): 159-161.

[12] Damaziak, K., Riedel, J., Gozdowski, D., Niemiec, J., Siennicka, A., Róg, D. (2017): Productive performance and egg quality of laying hens fed diets supplemented with garlic and onion extracts. - Journal of Applied Poultry Research 26(3): 337-349.

[13] Demir, E., Sarica, Ş., Özcan, M. A., Sui Mez, M. (2003): The use of natural feed additives as alternatives for an antibiotic growth promoter in broiler diets. - British Poultry Science 44(1): 44-45.

[14] Diaz Carrasco, J. M., Casanova, N. A., Fernández Miyakawa, M. E. (2019): Microbiota, Gut Health, and Chicken Productivity; What Is the Connection? - Microorganisms 7(10): 374.

[15] Ebesunun, M. O., Popoola, O. O., Agbedana, E. O., Olisekodiaka, J. M., Onuegbu, J. A., Onyeagala, A. A. (2007): The effect of garlic on plasma lipids and lipoproteins in rats fed on high cholesterol-enriched diet. - Biochemistry 19(2): 53-58.

[16] Edeoga, H. O., Okwu, D. E., Mbaebie, B. O. (2005): Phytochemical constituents of some Nigerian medicinal plants. - African Journal of Biotechnology 4(7): 685-688.

[17] Edeogu, C. O., Ezeonu, F. C., Okaka, A. N. C., Ekuma, C. E., Elom, S. O. (2007): Proximate compositions of staple food crops in Ebonyi state, South Eastern Nigeria. International Journal of Biotechnology \& Biochemistry 3(1): 57-68.

[18] Frankic, T., Voljc, M., Salobir, J., Rezar, V. (2009): Use of herbs and spices and their extracts in animal nutrition. - Acta Agriculturae Slovenica 94: 95-102.

[19] Goodarzi, M., Nanekarani, S., Landy, N. (2013): Effect of dietary supplementation with onion (Allium cepa L.) on performance, carcass traits, and intestinal microflora composition in broiler chickens. - Asian Pacific Journal of Tropical Disease 4(1): 297-301.

[20] Goodarzi, M., Nanekarani, S. (2014): Effect of onion extract in drink water on performance and carcass traits in broiler chickens. - IERI Procedia 8: 107-112.

[21] Guo, F. C., Kwakkel, R. P., Verstegen, M. W. A. (2000): The use of Chinese herbs as alternative for growth promoters in broiler diets. - In: Proceedings of the $21^{\text {st }}$ World's Poultry Congress (WPSA), Montreal, Canada.

[22] Hanieh, H., Narabara, K., Piao, M., Gerile, C., Abe, A., Kondo, Y. (2010): Modulatory effects of two levels of dietary Alliums on immune response and certain immunological variables, following immunization, in White Leghorn chickens. - Animal Science Journal 81(6): 673-680.

[23] Ibrahiem, A. I., Talib, A. E., Fathi, F. M. (2004): Effect of onion and/or garlic as feed additives on growth performance and immunity in broiler Muscovy ducks. - First Scientific Conference of Faculty of Veterinary Medicine, Benhar, pp. 236-247.

[24] Iji, P. A., Saki, A., Tivey, D. R. (2001): Body and intestinal growth of broiler chicks on a commercial starter diet. 1. Intestinal weight and mucosal development. - British Poultry Science 42(4): 505-513.

[25] Iqbal, A., Bayram, I. (2019): A Review-Use of onion juice and their product in animal nutrition and recent research of onion juice on laying hens. - The Journal of Animal and Plant Sciences 31(2): 377-385.

[26] Kandoliya, U. K., Bodar, N. P., Bajaniya, V. K., Bhadja, N. V., Golakiya, B. A. (2015): Determination of nutritional value and antioxidant from bulbs of different onion (Allium cepa) variety: A comparative study. - International Journal of Current Microbiology and Applied Sciences 4(1): 635-641.

[27] Keohavong, B., Bounyavong, S. (2018): Effects of Onion (Allium cepa L.) Extract on Growth Performance and Carcass Characteristics of Muscovy duck. - Department of Animal Science, Souphanouvong Journal University, Laos.

[28] Khaidem, A., Zuyie, R., Haque, N., Vidyarthi, V. K. (2019): Effect of garlic supplementation on performance, carcass traits, and blood profile of broiler chicken. International Journal of Bio-resource and Stress Management 10(3): 292-297. 
[29] Korpraditskul, V., Kasornpikul, C., Chalorsantisakul, S. (2009): Effect of tree onion extracts as prebiotics on newcastle disease vaccine titer in broiler. - Journal of ISSAAS [International Society for Southeast Asian Agricultural Sciences] (Philippines).

[30] Kothari, D., Lee, W. D., Niu, K. M., Kim, S. K. (2019): The genus Allium as poultry feed additive: A review. - Animals 9(12): 1032.

[31] Lampe, J. W. (1999): Health effects of vegetables and fruits: Assessing mechanisms of action in human experimental studies. - American Journal of Clinical Nutrition 70(3): 475490.

[32] Liguori, L., Califano, R., Albanese, D., Raimo, F., Crescitelli, A., Di Matteo, M. (2017): Chemical composition and antioxidant properties of five white onions (Allium cepa L.) landraces. - Journal of Food Quality, Article ID: 6873651.

[33] Mammo, M. (2012): The issue of feed-food competition and chicken production for the demands of foods of animal origin. - Asian Journal of Poultry Science 6(3): 31-43.

[34] Moorachian, M. E. (2000): Phytochemicals: Why and how. - Tastings 7: 4-5.

[35] Mulugeta, M., Worku, Z., Seid, A., Debela, L. (2019): Effect of garlic powder (Allium sativum) on performance of broiler chicken. - Livestock Research for Rural Development $31: 4$.

[36] Noman, Z. A., Hasan, M. M., Talukder, S., Sarker, Y. A., Paul, T. K., Sikder, M. H. (2015): Effects of garlic extract on growth, carcass characteristics, and haematological parameters in broilers. - Bangladesh Veterinarian 32(1): 1-6.

[37] Obasi, K. O., Chineze, N. C., Duru, M. C. (2009): Studies on the bacteriocidal effects of garlic (Allium sativum linn) on selected pathogenic bacteria. - Environmental Health and Human Development 10(2).

[38] Ogbonna, O. J., Udia, P. M., Abe, P. N., Omoregha, C. U., Anele, E. I. (2016): Phytochemical and proximate analysis, mineral and vitamin compositions of Allium Cepa bulb extract. - Advances in Biomedicine and Pharmacy 3(4): 181-186.

[39] Olusola, O. O., Tella, A. K., Olasunkanmi, A. A. (2018): Performance and meat quality attributes of broiler chickens fed onion skin extract and onion skin meal supplemented diets at the finisher stage. - Journal of Experimental Agriculture 24(1).

[40] Omar, A. E., Al-Khalaifah, H. S., Mohamed, W. A., Gharib, H. S., Osman, A., Al-Gabri, N. A., Amer, S. A. (2020): Effects of Phenolic-Rich Onion (Allium cepa L.) Extract on the Growth Performance, Behavior, Intestinal Histology, Amino Acid Digestibility, Antioxidant Activity, and the Immune Status of Broiler Chickens. - Frontiers in Veterinary Science 7: 728.

[41] Pareek, S., Sagar, N. A., Sharma, S., Kumar, V. (2017): Onion (Allium cepa L.). Fruit and vegetable phytochemicals: chemistry and human health. $-2^{\text {nd }}$ ed. Hoboken, NJ: Wiley Blackwell, pp. 1145-62.

[42] Rao, B. N. (2003): Bioactive phytochemicals in Indian foods and their potential in health promotion and disease prevention. - Asia Pacific Journal of Clinical Nutrition 12(1): 9-22.

[43] Saxena, M., Saxena, J., Nema, R., Singh, D., Gupta, A. (2013): Phytochemistry of medicinal plants. - Journal of Pharmacognosy and Phytochemistry 1(6): 168-182.

[44] Slavin, J. (2013): Fiber and prebiotics: mechanisms and health benefits. - Nutrients 5(4): 1417-1435.

[45] Swain, P., Sethy, K., Sahoo, P. R., Mishra, S. P., Nayak, S. M., Patro, P. (2017): Influence of Organic Dietary Supplementation on Physiological Performance in Japanese Quail (Coturnix japonica): A Critical Review. - International Journal of Pure and Applied Bioscience 5(5): 844-857.

[46] Ur Rahman, S., Khan, S., Chand, N., Sadique, U., Khan, R. U. (2017): In vivo effects of Allium cepa $\mathrm{L}$. on the selected gut microflora and intestinal histomorphology in broiler. Acta Histochemical 119(5): 446-450.

[47] Waleed, M. D., Hassan, S. Z., Mohamed, H. A., Soliman, M. Z., Maher, M. S., Nader, R. A., Abdel-Moneim, E., Taha, A. E., El-Tarabily, K. A., Mohamed, E. A. (2021): Impacts 
of onion and cinnamon supplementation as natural additives on the performance, egg quality and immunity in laying Japanese quail. - Poultry Science 100(12): 101482.

[48] Yadav, A. S., Kolluri, G., Gopi, M., Karthik, K., Singh, Y. (2016): Exploring alternatives to antibiotics as health promoting agents in poultry-A review. - Journal of Experimental Biology 4(3): 3-10.

[49] Yang, N., Jiang, R. S. (2005): Recent advances in breeding for quality chickens. - World's Poultry Science Journal 61(3): 373-381.

[50] Yousuf, M. N., Akter, S., Haque, M. I., Mohammad, N., Zaman, M. S. (2013): Compositional nutrient diagnosis (CND) of onion (Allium cepa L.). - Bangladesh Journal of Agricultural Research 38(2): 271-287.

[51] Zhao, X. X., Lin, F. J., Li, H., Li, H. B., Wu, D. T., Geng, F., Ma, W., Wang, Y., Miao, B. H., Gan, R. Y. (2021): Recent advances in bioactive compounds, health functions, and safety concerns of onion (Allium cepa L.). - Frontiers in Nutrition 8. DOI: $10.3389 /$ fnut.2021.669805 